\title{
WOMEN IN REPRODUCTIVE SCIENCE Anti-Müllerian hormone: a look back and ahead
}

\author{
Nathalie Josso \\ INSERM UMR_S 938, Centre de Recherche Saint-Antoine, Sorbonne-Université, Paris, France \\ Correspondence should be addressed to N Josso; Email: nathalie.josso@u-psud.fr
}

This paper forms part of a focus section on Women in Reproductive Science. The guest editor for this section was Professor Marilyn Renfree, Ian Potter Chair of Zoology, School of BioSciences, The University of Melbourne, Victoria, Australia

\begin{abstract}
Anti-Müllerian hormone (AMH) is a member of the TGF- $\beta$ family secreted by immature Sertoli cells and by granulosa cells of growing ovarian follicles. In males, it induces the regression of fetal Müllerian ducts and represses androgen synthesis through receptors located on the Leydig cell membrane. In female mice, AMH inhibits primary follicle recruitment and sensitivity to FSH. Measurement of circulating $\mathrm{AMH}$ is of value to pediatric endocrinologists allowing them to detect the presence and functional activity of testicular tissue without resorting to stimulation by human chorionic gonadotropin. In women, AMH levels are correlated with the size of the ovarian follicle pool and provide information on the likelihood of spontaneous or induced pregnancy.

Reproduction (2019) 157 F81-F89
\end{abstract}

\section{Introduction}

Anti-Müllerian hormone, $\mathrm{AMH}$ for friends, has an eventful history. Its existence was recognized in the middle of the 20th century (Jost 1953). Initially, AMH was thought to act exclusively in young male fetuses and as such did not appear particularly attractive to the medical community. The demonstration by Vigier et al. (1984) that AMH is produced by growing follicles in the adult ovary did nothing to change that opinion. However, when a team in Rotterdam built on Vigier's finding to show that the level of AMH in a woman's serum is correlated to the number of her ovarian follicles (de Vet et al. 2002, van Rooij et al. 2002), things started to change while biotechnology companies fought tooth and nail to win the market for AMH clinical assays.

I first fell in love with AMH in 1964 during Professor Jost's graduate course at the Paris Science Faculty. I had enrolled thinking that a brief introduction to basic science could be useful to an aspiring pediatric endocrinologist. Jost was a fascinating teacher. He made research sound so exciting that I upended my plans of a medical career and instead joined the National Institute for Health and Medical Research with the ambition of purifying the mysterious substance advertised by my mentor. Little did I imagine that it would take the efforts of three people during 20 years! The full story is told in the book 'Le Sexe des Anges: une histoire d'hormones' (Josso 2017). A short overview of my life is presented in Box 1.

\section{Alfred Jost and the AMH concept}

At the beginning of fetal life, the reproductive tract is sexually undifferentiated. Both males and females possess Wolffian ducts, the primordia for male accessory organs and Müllerian ducts which in females develop into uterus and tubes. If testes are present, Wolffian ducts persist and Müllerian ducts disappear. The idea that a testicular product distinct from testosterone is responsible for Müllerian regression was born in 1953, following the seminal experiments of Jost (1953). Jost grafted a testosterone crystal near the ovary of a rabbit fetus and obtained a florid development of Wolffian ducts, but no regression of Müllerian ducts. These disappeared only if a fragment of testicular tissue was implanted instead. Jost concluded that a separate factor, different from testosterone, is responsible for Müllerian regression in mammals. He called it the Müllerian inhibitor, subsequently known as Müllerian inhibiting substance (MIS), factor (MIF) or anti-Müllerian hormone $(\mathrm{AMH})$, the term generally in use today.

\section{Régine Picon's contribution: the bioassay for anti- Müllerian activity}

The AMH concept was not adopted without a struggle. 'Professional' embryologists, for instance, Professor Etienne Wolff in France, insisted that testosterone alone was responsible for male sex differentiation, 


\section{Box 1: Nathalie Josso}

Napoleon reportedly said that he never employed generals with consistent bad luck. Luck has played a great role in my life. I was lucky to have a father who believed in women's education and expected his daughters to live up to his expectations. Without my husband, François Josso, at my side, I would never have managed to raise a family and pursue a demanding scientific career at the same time. Luck again led me to Professor Alfred Jost's laboratory where I first fell in love with anti-Müllerian hormone, AMH. And had I been an experienced biochemist instead of an innocent pediatric endocrinologist, I would never have dreamed of trying to isolate a substance about which nothing was known, apart from the fact that it was not testosterone.

My luck held once I embarked on what promised to be a wild goose chase. Without Jean-Yves Picard, my scientific partner since 1975, I would have failed miserably. For nearly 50 years, Jean-Yves and I have worked together. From the very beginning, we had decided that all decisions should be jointly agreed on. This led to interminable discussions, each of us trying to persuade the other so that finally it was impossible to decide who had won because we both had contributed ideas to the project. We understood each other so well we did not even need to finish our sentences and other members of the team felt excluded. Our passion

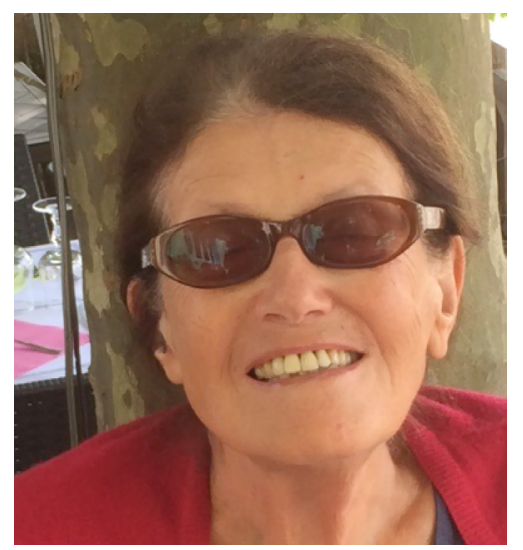
for $\mathrm{AMH}$ was catching on and attracted very talented people, Bernard Vigier, Nathalie di

Clemente, Chrystèle Racine, Rodolfo Rey, Laurence Mallet to name only a few. We even managed to seduce Richard Cate who had cloned the AMH gene working for Patricia Donahoe in Boston. Since he had beaten us at the finish, we reasoned that it was better to have him in our team rather than against and we were right. Without him, we would never have cloned the AMH receptor.

Medicine helped too. I was trained as a pediatric endocrinologist and even after I joined INSERM, an institute for medical research, I saved time for clinical activity. It focused on defects in sex differentiation and was instrumental in bringing AMH from bench to bedside. I believe it is important for researchers to have another activity. A lot can go wrong in research. Experiments don't work, papers get rejected, promotions are slow. Helping patients or teaching students saves you from a feeling of complete failure. Furthermore, clinical data are useful to research. Rodolfo Rey and I discovered that $\mathrm{AMH}$ is downregulated by testosterone by studying patients with precocious puberty or androgen insensitivity.

Failure is more or less inevitable at the beginning of a new project. Things nearly never work out the first time around. I spent nearly 6 months trying to clean seminiferous tubules from interstitial tissue to prove the origin of AMH. It is very difficult to decide whether it is better to pursue or give up. Experienced investigators can help young ones to find out whether the problems can be overcome by hard work or whether they are due to parameters beyond one's control. The one and only time an experiment worked for me the first time was also the last. The vision of a shining halo formed by the $\mathrm{AMH}$ receptor around a rabbit fetal Müllerian duct was the last occasion I experienced the joy of a successful personal experiment. Of course, as a team leader, the achievements of my co-workers made me very proud and happy but the elation is not the same.

I now belong to a large INSERM research unit at Hospital Saint-Antoine in Paris. I work with Jean-Yves on the Persistent Müllerian Duct syndrome, a rare condition usually due to mutations of the $\mathrm{AMH}$ or $\mathrm{AMH}$ type 2 receptor genes. We collaborate with Rodolfo Rey who now heads a major research center in Buenos-Aires. Voltaire wrote in 'Candide': 'Il faut cultiver notre jardin'. I follow his advice, I grow roses in my garden.

\section{Some important articles}

Cohen-Haguenauer O, Picard JY, Mattei MG, Serero S, Nguyen VC, de Tand MF, Guerrier D, Hors-Cayla MC, Josso N \& Frézal J 1987 Mapping of the gene for anti-Müllerian hormone to the short arm of human chromosome 19. Cytogenetics and Cell Genetics 44 2-6. (https://doi. org/10.1159/000132332)

Dutertre M, Rey R, Porteu A, Josso N \& Picard JY 1997 A mouse Sertoli cell line expressing anti-Müllerian hormone and its type II receptor. Molecular and Cellular Endocrinology 136 57-65. (https://doi.org/10.1016/S0303-7207(97)00214-1)

Josso N 1971 Interspecific character of the Müllerian-inhibiting substance: action of the human fetal testis, ovary and adrenal on the fetal rat Müllerian duct in organ culture. Journal of Clinical Endocrinology and Metabolism 32 404-409. (https://doi.org/10.1210/jcem-32-3-404)

Josso N 1972 Permeability of membranes to the Müllerian inhibiting substance synthesized by the human fetal testis. Journal of Clinical Endocrinology and Metabolism 34 265-270. (https://doi.org/10.1210/jcem-34-2-265)

Josso N 1973 In vitro synthesis of Müllerian-inhibiting hormone by seminiferous tubules isolated from the calf fetal testis. Endocrinology 93 829-834. (https://doi.org/10.1210/endo-93-4-829)

Josso N 1991 Remembrance of Dr. Alfred Jost. Endocrinology 129 2274-2276. (https://doi.org/10.1210/endo-129-5-2274)

Josso N 1995 Paediatric applications of anti-Müllerian hormone research. Hormone Research 43 243-248. (https://doi.org/10.1159/000184300)

Josso N, Picard JY, Rey R \& di Clemente N 2006 Testicular anti-Müllerian hormone: history, genetics, regulation and clinical applications. Pediatric Endocrinology Reviews 3 347-358.

Knebelmann B, Boussin L, Guerrier D, Legeai L, Kahn A, Josso N \& Picard JY 1991 Anti-Müllerian hormone bruxelles: a nonsense mutation associated with the persistent Müllerian duct syndrome. PNAS 88 3767-3771. (https://doi.org/10.1073/pnas.88.9.3767)

Lukas-Croisier C, Lasala C, Nicaud J, Bedecarras P, Kumar TR, Dutertre M, Matzuk MM, Picard JY, Josso N \& Rey R 2003 Follicle-stimulating hormone increases testicular anti-Müllerian hormone $(\mathrm{AMH})$ production through Sertoli cell proliferation and a nonclassical cyclic adenosine 5'-monophosphate-mediated activation of the AMH gene. Molecular Endocrinology 17 550-561. (https://doi.org/10.1210/me.2002-0186)

Picard JY, Cate RL, Racine C \& Josso N 2017 The persistent Müllerian duct syndrome: an update based upon a personal experience of 157 cases. Sexual Development 11 109-125. (https://doi.org/10.1159/000475516)

Picard JY \& Josso N 1984 Purification of testicular anti-Müllerian hormone allowing direct visualization of the pure glycoprotein and determination of yield and purification factor. Molecular and Cellular Endocrinology 34 23-29. (https://doi.org/10.1016/0303-7207(84)90155-2)

Picard JY, Tran D \& Josso N 1978 Biosynthesis of labelled anti-Müllerian hormone by fetal testes: evidence for the glycoprotein nature of the hormone and for its disulfide-bonded structure. Molecular and Cellular Endocrinology 12 17-30. (https://doi.org/10.1016/0303-7207(78)90098-9) 
Racine C, Pask AJ, Wijayanti GE, di Clemente N, Picard JY, Shaw G, Renfree MB \& N Josso 2009 Early expression of the androgen receptor in the Sertoli cells of a marsupial coincides with downregulation of anti-Müllerian hormone at the time of urogenital virilization. Sexual Development $\mathbf{3}$ 317-325. (https://doi.org/10.1159/000273263)

Racine C, Rey R, Forest MG, Louis F, Ferre A, Huhtaniemi I, Josso N \& di Clemente N 1998 Receptors for anti-Mullerian hormone on Leydig cells are responsible for its effects on steroidogenesis and cell differentiation. PNAS 95 594-599. (https://doi.org/10.1073/pnas.95.2.594)

Rey R, Lordereau-Richard I, Carel JC, Barbet P, Cate RL, Roger M, Chaussain JL \& Josso N 1993 Anti-Müllerian hormone and testosterone serum levels are inversely related during normal and precocious pubertal development. Journal of Clinical Endocrinology and Metabolism 77 1220-1226.

Rey R, Mebarki F, Forest MG, Mowszowicz I, Cate RL, Morel Y, Chaussain JL \& Josso N 1994 Anti-Müllerian hormone in children with androgen insensitivity. Journal of Clinical Endocrinology and Metabolism 79 960-964.

Vigier B, Picard JY, Tran D, Legeai L \& Josso N 1984 Production of anti-Müllerian hormone: another homology between Sertoli and granulosa cells. Endocrinology 114 1315-1320. (https://doi.org/10.1210/endo-114-4-1315)

Müllerian regression included. Their skepticism was understandable. The father of the $\mathrm{AMH}$ concept, Alfred Jost, was unable to suggest, let alone prove, its biochemical nature or its cellular origin. Fetal surgery, the method he had used to demonstrate the existence of $\mathrm{AMH}$, was out of the reach of ordinary mortals. Thus, for 15 years, AMH remained a mystery. Then, in 1969, Régine Picon, a member of Jost's group at Paris University, set the ball rolling again (Picon 1969).

Since this issue is about women in Reproduction, I would like to take this opportunity to pay a tribute to Régine, whose contribution to $\mathrm{AMH}$ research does not get the recognition it deserves. Born in Sénégal, a former French colony in Africa, Régine Picon had studied zoology and botany in Dakar. She had published a paper on the development of the genital tract of sharks. After her marriage, she came to Paris and in 1960 joined the Jost group. There, her favorite species not being available, she switched to rats and undertook to study the effect of the rat fetal testis upon rat Müllerian ducts in organ culture. She dissected the reproductive tract of a sexually undifferentiated rat fetus and placed it on a metal grid in a dish containing a nutritive solution. Then, she placed a fetal rat testis next to it. Three days later, she checked the result by histological examination. At the start of the culture period, the Müllerian duct was intact. At the end, it was gone! Régine demonstrated that the Müllerian duct loses its responsiveness to $\mathrm{AMH}$ very early in fetal life, while in contrast, the testis retains its anti-Müllerian activity until birth. Régine's findings represent a giant step forward because the bioassay she set up is accessible to any reasonably gifted researcher. Her work has been the key to all the early developments in $\mathrm{AMH}$ research.

\section{The basics}

Most hormones are steroids, peptides or proteins. Steroids are small, so they are expected to cross obstacles impermeable to proteins. Insertion of a piece of dialysis membrane between the testis and the fetal Müllerian duct in the bioassay abolished testicular anti-Müllerian activity, proving that the size of the AMH molecule was greater than 15,000 Da. Therefore, AMH was probably a protein, not a steroid or a small peptide (Josso 1972).
Which cells produce $\mathrm{AMH}$ ? To find out, the easiest way would have been to challenge a section of testicular tissue with a specific anti-AMH antibody but that was not available. Failing that, one could try to separate interstitial tissue from seminiferous tubules to test their anti-Müllerian activity separately. Rodents, let alone fetal ones, were too small but calf fetal testes, which could be obtained at a slaughter house proved suitable. After several months spent in trying to clean seminiferous tubules without harming them, it appeared that antiMüllerian activity was carried by seminiferous tubules (Josso 1973). The question was not completely solved, however. Fetal seminiferous tubules contain a mixture of gonocytes and Sertoli cells. Mechanical separation was impossible without micro-manipulation instruments. But there was another way out. Germ cells are very sensitive to ionizing radiation. After exposure of fetal testicular tissue to X-rays, germ cells had disappeared but anti-Müllerian activity was not affected (Blanchard \& Josso 1974). The Sertoli cell origin of $\mathrm{AMH}$ was confirmed later by immunocytochemistry applied to the calf (Hayashi et al. 1984) and human (Tran et al. 1987) fetal testis.

\section{$\mathrm{AMH}$ is a glycoprotein}

Establishing that $\mathrm{AMH}$ is a macromolecule secreted by fetal Sertoli cells was just the beginning. The next challenge was purification, using the only available tool, the AMH bioassay. Would the fetal rat Müllerian duct respond to $\mathrm{AMH}$ produced by other species? If not, the perspective of purifying $\mathrm{AMH}$ from the testes of fetal rats was not appealing. Fortunately, AMH activity is interspecific, at least between mammals (Josso 1971) and a larger species, the bovine, was chosen for use in the bioassay.

But how is one expected to purify a testicular protein using a bioassay? Well, as we quickly found out, not by adding a testicular homogenate to the culture medium. After 3 days in culture, the target organ was dead as a doornail. Better results were obtained by incubating the bovine testicular tissue and then using the incubation medium to culture the fetal reproductive tract (Josso et al. 1975). The incubation medium exhibited clear signs of anti-Müllerian activity and became the starting 
material for further purification. Most methods however require minimal information on the characteristics of the substance of interest, at least an approximate molecular weight or isoelectric point. We - myself and my scientific partner Jean-Yves Picard - were forced to proceed by trial and error. We first determined the molecular weight of $\mathrm{AMH}$ using gel filtration and reported a mass of approximately 215,000 Da (Picard \& Josso 1976). The medium with anti-Müllerian activity was then submitted to density gradient sedimentation with surprising results: the $\mathrm{AMH}$ molecule had shrunk to $124,000 \mathrm{Da}$ ! The discrepancy suggested that AMH might be a glycoprotein. Evidence for this hypothesis was obtained by incubating fetal bovine testicular tissue in the presence of tritiated fucose: anti-Müllerian activity always co-purified with radioactivity (Picard et al. 1978). Two years later, a Boston team also led by a woman, Patricia Donahoe, confirmed the glycoprotein nature of AMH using lectin-affinity chromatography (Budzik et al. 1980). In our hands, analysis of the incubation medium by polyacrylamide electrophoresis showed a single major radioactive peak of $140,000 \mathrm{Da}-70,000$ if the electrophoresis was carried out in reducing conditions, suggesting that $\mathrm{AMH}$ is a homodimer linked by disulfide bonds (Picard et al. 1978).

\section{Monoclonal antibodies to the rescue}

It then became obvious that $\mathrm{AMH}$ purification would never be achieved by standard biochemical methods alone: even in most purified fractions, the $\mathrm{AMH}$ concentration was minimal compared to the contaminants. Staining of polyacrylamide gels failed to show a protein band at the site of the radioactive peak. Immunochromatography was a possibility but how to raise a specific antibody against an impure antigen? Perhaps monoclonal antibody technology could help, provided we could come up with a suitable screening method. Bernard Vigier, a former student of Jost who had joined us, prepared monoclonal antibodies from mice immunized with partially purified AMH and added fucose-labeled semi-purified incubation medium to cultured hybridomas. Three out of a hundred secreted antibodies precipitated the radioactivity. One hybridoma was cloned and grown in mice: the monoclonal antibody abolished anti-Müllerian activity of partially purified AMH (Vigier et al. 1982b) and was successfully used to purify bovine AMH to homogeneity (Picard \& Josso 1984). Vigier et al. (1982a) went on to devise a radioimmunoassay which replaced the tedious qualitative bioassay. Other monoclonal antibodies against bovine $\mathrm{AMH}$ were used in Boston for possible AMH purification (Budzik et al. 1985). Bernard Vigier's initial antibodies have recently been used to set up an immunoassay for bovine AMH (Arouche et al. 2015). The screening method was so crude that only antibodies with very high affinity were picked up!

\section{AMH belongs to the transforming growth factor $\beta$ family}

Monoclonal antibodies raised against bovine $\mathrm{AMH}$ do not recognize human $\mathrm{AMH}$ and cannot be used to purify it. Two groups undertook to clone the AMH gene. Jean-Yves Picard, in Paris, cloned the cDNA for bovine AMH (Picard et al. 1986) but before he could finish the job, Richard Cate, an investigator in a biotechnology company, in collaboration with Patricia Donahoe, cloned the human gene and produced recombinant human $\mathrm{AMH}$ (Cate et al. 1986). The human gene measures only $2.8 \mathrm{kbp}$ and contains five exons. Richard Cate noticed that the $3^{\prime}$ end of the 5th exon is extremely guanine/cytosine rich, a characteristic of the transforming growth factor $\beta$ (TGF- $\beta$ ) family. Indeed, as shown in Cate's seminal paper, AMH is a distant member of this family with a $28 \%$ homology to TGF- $\beta$ itself for the C-terminal domain of the protein. The AMH gene has been mapped to chromosome 19 p13.3 (CohenHaguenauer et al. 1987).

The AMH gene codes for a $70 \mathrm{kDa}$ monomer of 560 amino acids. After elimination of the signal peptide, it dimerizes through disulfide bonds giving rise to a $140 \mathrm{kDa}$ AMH full-length proprotein. Like the other members of the TGF- $\beta$ superfamily, the proprotein undergoes proteolytic cleavage at a dibasic site to yield a short 109 amino acid C-terminal domain and a 426 $\mathrm{N}$-terminal one (Pepinsky et al. 1988). The C-terminus, the only one with homology to the TGF- $\beta$ family, carries the bioactivity, the $\mathrm{N}$-terminus playing a stabilizing role (Wilson et al. 1993). Cleavage is required for $\mathrm{AMH}$ bioactivity - the $\mathrm{N}$ and $\mathrm{C}$ fragments remain associated in a non-covalent complex (Pepinsky et al. 1988). The identity of the proteases responsible for AMH cleavage in vivo has not yet been determined. Possible candidates include plasmin, a serine protease (Pepinsky et al. 1988) or proprotein convertases such as PCKS3 and PCSK5 (Nachtigal \& Ingraham 1996).

\section{The AMH gene is tightly regulated}

Sertoli cells produce $\mathrm{AMH}$ as early as the seventh post-natal week, and production continues long after Müllerian ducts have disappeared. After birth, AMH levels remain high up to puberty and then decline rapidly falling to minimal levels in the adult. Comparably low amounts are produced by ovarian granulosa cells (Vigier et al. 1984) from the perinatal period up to menopause (reviewed in Visser et al. 2006, Dewailly et al. 2014). The first immunoassays for AMH in human serum were adapted to the high concentrations seen in prepubertal boys (Baker et al. 1990, Hudson et al. 1990, Josso et al. 1990) and were relatively insensitive. The realization that AMH levels in women are correlated with ovarian reserve and may be clinically useful led to a flurry of new assays with high sensitivity but not necessarily in 
agreement with one another (Nelson et al. 2015, Pigny et al. 2016). An international AMH standard has not yet been agreed upon.

The expression of $\mathrm{AMH}$ is regulated differently in males and females. In males, intratesticular testosterone concentration curtails $\mathrm{AMH}$ secretion provided the androgen receptor is present on the Sertoli cell membrane (Rey et al. 1993). Androgen acts through the binding sites for steroidogenic factor 1 (SF-1) on the proximal promoter (Edelsztein et al. 2018). FSH has the opposite effect; it stimulates $\mathrm{AMH}$ production but to a lesser degree (Al Attar et al. 1997). Cyclic AMP-mediated stimulation by $\mathrm{FSH}$ uses response elements located on both the proximal and distal promoter (Lasala et al. 2011). Transcription factors SOX9, SF-1, GATA4, WT-1 or DAX-1 regulate $\mathrm{AMH}$ gene transcription either by direct binding to specific response elements in the $\mathrm{AMH}$ proximal promoter or by protein-protein interaction (reviewed in Lasala et al. 2011).

In females, $\mathrm{AMH}$ production is maximal in small growing follicles becoming undetectable in large ones (reviewed in Taieb et al. 2011) Estrogen inhibits (Grynberg et al. 2012) and gonadotropins stimulate (Taieb et al. 2011, Pierre et al. 2013) AMH transcription in luteinized granulosa cells from women undergoing in vitro fertilization. AMH transcription in granulosa cells is upregulated by bone morphogenetic proteins (Shi et al. 2009) and by co-culture with oocytes of growing follicles (Salmon et al. 2004, Convissar et al. 2017). Hormonal regulatory mechanisms are disrupted in women with polycystic ovaries (Pierre et al. 2013, 2017).

\section{AMH signaling}

Like all members of the TGF- $\beta$ superfamily, AMH uses two serine-protein kinases for signaling. The primary receptor, AMHR2, is AMH specific, and it was cloned in 1994 independently by a Dutch and by a French team. Neither used the classical AMH target organ to construct a cDNA library. In Rotterdam, Willy Baarends and Axel Themmen were interested in androgen-responsive Sertoli cell genes and stumbled upon a cDNA appearing to encode a novel receptor of the TGF- $\beta$ superfamily (Baarends et al. 1994). Based upon its expression in the mesenchymal cells surrounding the fetal Müllerian duct, they rightly suggested that the cDNA clone encoded an $\mathrm{AMH}$ receptor. Finally, it turned out that the receptor was not androgen responsive after all! In Paris, at the same time, Nathalie di Clemente, Richard Cate and their co-workers set out to clone the $\mathrm{AMH}$ receptor gene by more conservative methods. To construct a cDNA library, instead of the fetal Müllerian duct, they chose a lesserknown AMH target organ, the fetal ovary which is larger and easier to dissect. They screened the library with a consensus sequence of the TGF- $\beta$ receptor superfamily and detected a clone which differed from the consensus sequence by a single amino acid but had the pattern of expression expected for an $\mathrm{AMH}$ receptor. By transiently expressing the transcript in COS cells, they were able to prove binding to $\mathrm{AMH}$ (di Clemente et al. 1994).

In the TGF- $\beta$ superfamily, the primary receptor binds the ligand but another receptor, called type 1 , is required to initiate signaling. Unlike the type 2 receptors, which are reasonably specific, type 1 receptors are common to subsets of TGF- $\beta$ family members, and it made sense to look for the AMH type 1 receptor among those already cloned. This approach was successful. The AMH signaling cascade borrows type 1 receptors, ACVR1 (ALK2) and BMPR1A (ALK3), and rSmads 1, 5 and 8, from the BMP family (Clarke et al. 2001, Visser et al. 2001, Jamin et al. 2002). BMPR1B (ALK6) acts as a negative regulator of intracellular signaling (Gouédard et al. 2000, Belville et al. 2005). In summary (Orvis et al. 2008), expression of Wnt7a by the mesothelium together with SF-1 and WT-1 expression in the coelomic epithelium activates the expression of AMHR2 by coelomic epithelial cells which then migrate to the peri-Müllerian mesenchyme.

After binding to AMH, AMHR2 recruits ACVR1 and BMPR1A to phosphorylate Smads 1, 5 or 8 . This initiates the transcription of target genes mediating the regression of Müllerian duct epithelium. The identity of the target genes is not clear at the present time, a member of the matrix metalloproteinase gene family (Roberts et al. 2002) or a member of the Wnt family (Hossain \& Saunders 2003, Kobayashi et al. 2011) are possible candidates.

To bind AMHR2, the full-length AMH proprotein must be cleaved; dissociation of the non-covalently bound fragments is not required. After binding of cleaved $\mathrm{AMH}$ to AMHR2, dissociation occurs, the $\mathrm{N}$-terminal fragment is lost, the type 1 receptor is recruited and signaling begins (di Clemente et al. 2010) (Fig. 1). Because full-length $\mathrm{AMH}$ is biologically inactive, it has been suggested that measuring it separately might provide an indication of $\mathrm{AMH}$ bioactivity in body fluids (Pankhurst \& McLennan 2016, Pierre et al. 2016). There are marked differences in the proportion of cleaved versus fulllength $\mathrm{AMH}$ according to sex, age and clinical status (Mamsen et al. 2015), but interpretation is difficult.

\section{Extra-Müllerian roles of $\mathrm{AMH}$}

In males, Sertoli cells continue to produce AMH long after the Müllerian ducts have completely disappeared, suggesting that $\mathrm{AMH}$ may play other roles. Some have been confirmed experimentally while others are hypotheses inferred from correlations with $\mathrm{AMH}$ ontogeny (Morgan et al. 2017) or with the location of the AMH receptor. AMHR2 is present on the membrane of Leydig cells, where it mediates the repression of steroidogenic enzymes and downregulates testosterone secretion (Racine et al. 1998). Since then, AMHR2 has been identified in the nervous system: motoneurons (Wang et al. 2005), GnRH neurons (Cimino et al. 


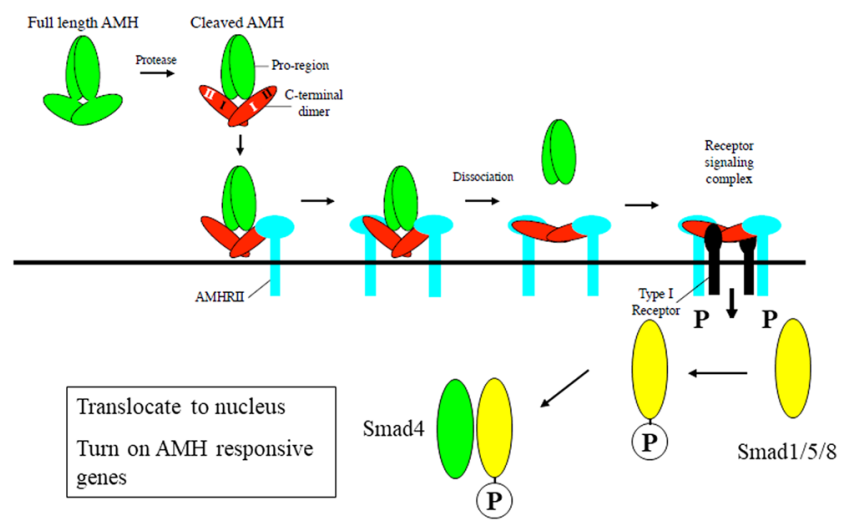

Figure $1 \mathrm{~A}$ suggested model for the assembly of the AMH signaling complex. Cleavage of full-length $\mathrm{AMH}$ results in a conformational change in the C-terminus dimer (indicated by the color change from green to red), allowing binding of two molecules of AMHR2. Binding induces dissociation of the $\mathrm{N}$-terminal dimer via a negative interaction between the receptor and the $\mathrm{N}$-terminal-binding sites on the C-terminal dimer (indicated by the shape change). Finally, the type 1 receptor is recruited, receptor Smads 1, 5 or 8 are phosphorylated, bind to Smad 4 and enter the nucleus to turn on $\mathrm{AMH}$-responsive genes. The type 1 and 2 receptor-binding sites on the C-terminal dimer are indicated by either a 1 or a 2 . Reproduced from di Clemente et al. (2010), with permission.

2016), pituitary gonadotropes (Garrel et al. 2016), the developing and adult brain (Lebeurrier et al. 2008) and the cerebellum (Wittmann \& McLennan 2011). In the ovaries, $\mathrm{AMH}$ inhibits estrogen production by granulosa cells (di Clemente et al. 1994) and inhibits primordial follicle recruitment as well as the responsiveness of growing follicles to follicle-stimulating hormone (reviewed in Visser \& Themmen 2014).

Teleost fishes have no Müllerian ducts, but they do have amh orthologs - some species even have two! The second copy is located on the $Y$ chromosome and acts as a male determining factor (Hattori et al. 2012, Yamamoto et al. 2014). Teleost fishes display a bewildering diversity of all biological aspects including sex determination and differentiation. Not surprisingly, the variability extends to the structure, expression and function of amh (Pfennig et al. 2015); nevertheless, regulation of germ cell proliferation and follicular development appears to be a conserved function that preceded Müllerian duct evolution during phylogeny (Morinaga et al. 2007).

\section{Clinical relevance}

Measurement of circulating $\mathrm{AMH}$ by immunoassay is increasingly used for diagnostic purposes. In prepubertal children, it detects the presence of testicular tissue and explores its functional activity (reviewed in Freire et al. 2018). In the persistent Müllerian duct syndrome, $\mathrm{AMH}$ level distinguishes between mutations of the $\mathrm{AMH}$ or AMHR2 genes (Picard et al. 2017). In women, AMH level provides indirect, non-invasive information on

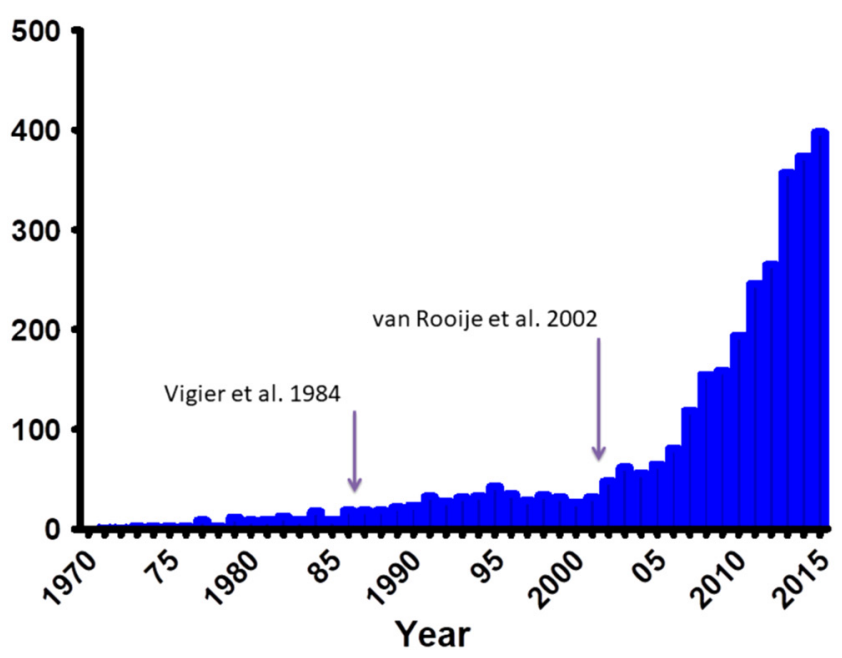

Figure 2 Number of yearly publications retrieved from PubMed (NLM) using the keyword AMH or its synonyms. Vigier et al. (1984) showed that $\mathrm{AMH}$ is produced by the adult ovary and van Rooij et al. (2002) showed the correlation between the level of circulating AMH and the state of ovarian reserve. Only then did the number of AMH publications grow dramatically.

the size of the follicle pool, hence, its use in assisted reproduction; however, it does not predict the probability of implantation or live birth (Pilsgaard et al. 2018). $\mathrm{AMH}$ blood concentration is extremely high in active granulosa-cell tumors (Gustafson et al. 1992, Rey et al. 1996) and usually more than twice the normal level in the polycystic ovarian syndrome (Pellatt et al. 2007). The role and regulation of ovarian $\mathrm{AMH}$ are targets of active ongoing investigation, deserving of a review in their own right.

Patricia Donahoe has promoted AMH as a biotherapeutic agent for gynecological cancer (Park et al. 2017). In mice co-administration of AMH protects the germline during chemotherapy (Kano et al. 2017, Sonigo et al. 2019) Clinical trials should be carried out to bear out these claims in women but unfortunately $\mathrm{AMH}$ is not available for clinical use at the present time.

\section{Conclusion}

At a time when medical research is funded only if it holds promise for medical applications, the AMH story among many others shows that this approach can be terribly wrong. AMH started out as a mysterious and perhaps imaginary fetal testicular hormone. As such, it could not be of the slightest practical use and if the present funding rules had applied 70 years ago, AMH would never have been discovered, let alone purified. Figure 2 shows the number of papers referenced over time by the National Library of Medicine, USA, with the keyword 'AMH' or its synonyms. Initially, there were only a handful each year but in 2002, the year the Rotterdam group reported correlation with ovarian 
reserve, the numbers exploded and now surpass 400 per year and counting! (Fig. 2). AMH has even been detected in the central nervous system, an unexpected promotion for a sex hormone! So please judge scientific projects according to their scientific merits and they may eventually lead to medical progress.

\section{Declaration of interest}

The author declares that there is no conflict of interest that could be perceived as prejudicing the impartiality of this review.

\section{Funding}

This review did not receive any specific grant from any funding agency in the public, commercial or not-for-profit sector.

\section{References}

Al Attar L, Noël K, Dutertre M, Belville C, Forest MG, Burgoyne PS, Josso N \& Rey R 1997 Hormonal and cellular regulation of Sertoli cell anti-Müllerian hormone production in the postnatal mouse. Journal of Clinical Investigation 100 1335-1343. (https://doi.org/10.1172/ JCl119653)

Arouche N, Picard JY, Monniaux D, Jamin SP, Vigier B, Josso N, Cate RL, di Clemente N \& Taieb J 2015 The BOC elisa, a ruminant-specific AMH immunoassay, improves the determination of plasma AMH concentration and its correlation with embryo production in cattle. Theriogenology 84 1397-1404. (https://doi.org/10.1016/j.theriogenology.2015.07.026)

Baarends WM, van Helmond MJL, Post $M$, van der Schoot PJ, Hoogerbrugge JW, De Winter JP, Uilenbroek JTJ, Karels B, Wilming LG \& Meijers JHC 1994 A novel member of the transmembrane serine/ threonine kinase receptor family is specifically expressed in the gonads and in mesenchymal cells adjacent to the Müllerian duct. Development 120 189-197.

Baker ML, Metcalfe SA \& Hutson JM 1990 Serum levels of Mullerian inhibiting substance in boys from birth to 18 years, as determined by enzyme immunoassay. Journal of Clinical Endocrinology and Metabolism 70 11-15. (https://doi.org/10.1210/jcem-70-1-11)

Belville C, Jamin SP, Picard JY, Josso N \& di Clemente N 2005 Role of type 1 receptors for anti-Mullerian hormone in the SMAT-1 Sertoli cell line. Oncogene 24 4984-4992. (https://doi.org/10.1038/sj.onc.1208686)

Blanchard MG \& Josso N 1974 Source of the anti-Müllerian hormone synthesized by the fetal testis: Müllerian-inhibiting activity of fetal bovine Sertoli cells in tissue culture. Pediatric Research 8 968-971. (https://doi. org/10.1203/00006450-197412000-00011)

Budzik GP, Swann DA, Hayashi A \& Donahoe PK 1980 Enhanced purification of Müllerian inhibiting substance by lectin affinity chromatography. Cell 21 909-915. (https://doi.org/10.1016/0092-8674(80)90454-7)

Budzik GP, Donahoe PK \& Hutson JM 1985 A possible purification of Müllerian inhibiting substance and a model for its mechanism of action. In Developmental Mechanisms, Normal and Abnormal: Progress in Clinical and Biological Research, pp 207-223. Ed JW Lash. New York: Alan R Liss.

Cate RL, Mattaliano RJ, Hession C, Tizard R, Farber NM, Cheung A, Ninfa EG, Frey AZ, Gash DJ \& Chow EP 1986 Isolation of the bovine and human genes for Müllerian inhibiting substance and expression of the human gene in animal cells. Cell 45 685-698. (https://doi. org/10.1016/0092-8674(86)90783-X)

Cimino I, Casoni F, Liu X, Messina A, Parkash J, Jamin SP, CatteauJonard S, Collier F, Baroncini M, Dewailly D et al. 2016 Novel role for anti-Mullerian hormone in the regulation of $\mathrm{GnRH}$ neuron excitability and hormone secretion. Nature Communications 7 10055. (https://doi. org/10.1038/ncomms10055)

Clarke TR, Hoshiya Y, Yi SE, Liu XH, Lyons KM \& Donahoe PK 2001 Müllerian inhibiting substance signaling uses a bone morphogenetic protein (BMP)-like pathway mediated by ALK2 and induces Smad6 expression. Molecular Endocrinology 15 946-959. (https://doi. org/10.1210/mend.15.6.0664)

Cohen-Haguenauer O, Picard JY, Mattei MG, Serero S, Nguyen VC, de Tand MF, Guerrier D, Hors-Cayla MC, Josso N \& Frézal J 1987 Mapping of the gene for anti-Müllerian hormone to the short arm of human chromosome 19. Cytogenetics and Cell Genetics 44 2-6. (https://doi. org/10.1159/000132332)

Convissar S, Armouti M, Fierro MA, Winston NJ, Scoccia H, Zamah AM \& Stocco C 2017 Regulation of AMH by oocyte-specific growth factors in human primary cumulus cells. Reproduction 154 745-753. (https://doi. org/10.1530/REP-17-0421)

de Vet A, Laven JS, de Jong FH, Themmen AP \& Fauser BCJM 2002 AntiMüllerian hormone serum levels: a putative marker for ovarian aging. Fertility and Sterility 77 357-362. (https://doi.org/10.1016/S00150282(01)02993-4)

Dewailly D, Andersen CY, Balen A, Broekmans F, Dilaver N, Fanchin R, Griesinger G, Kelsey TW, La Marca A, Lambalk C et al. 2014 The physiology and clinical utility of anti-Mullerian hormone in women. Human Reproduction Update 20 370-385. (https://doi.org/10.1093/ humupd/dmt062)

di Clemente N, Goxe B, Remy JJ, Cate RL, Josso N, Vigier B \& Salesse R 1994 Inhibitory effect of AMH upon the expression of aromatase and LH receptors by cultured granulosa cells of rat and porcine immature ovaries. Endocrine 2 553-558.

di Clemente N, Jamin SP, Lugovskoy A, Carmillo P, Ehrenfels C, Picard JY, Whitty A, Josso N, Pepinsky RB \& Cate RL 2010 Processing of antiMullerian hormone regulates receptor activation by a mechanism distinct from TGF- $\beta$. Molecular Endocrinology 24 2193-2206. (https:// doi.org/10.1210/me.2010-0273)

Edelsztein NY, Racine C, di Clemente N, Schteingart HF \& Rey RA 2018 Androgens downregulate anti-Mullerian hormone promoter activity in the Sertoli cell through the androgen receptor and intact steroidogenic factor 1 sites. Biology of Reproduction 99 1303-1312. (https://doi. org/10.1093/biolre/ioy152)

Freire AV, Grinspon RP \& Rey RA 2018 Importance of serum testicular protein hormone measurement in the assessment of disorders of sex development. Sexual Development 12 30-40. (https://doi. org/10.1159/000479572)

Garrel G, Racine C, L'Hote D, Denoyelle C, Guigon CJ, di Clemente N \& Cohen-Tannoudji J 2016 Anti-Mullerian hormone: a new actor of sexual dimorphism in pituitary gonadotrope activity before puberty. Scientific Reports 6 23790. (https://doi.org/10.1038/srep23790)

Gouédard L, Chen YG, Thevenet L, Racine C, Borie S, Lamarre I, Josso N, Massagué J \& di Clemente N 2000 Engagement of bone morphogenetic protein type IB receptor and Smad1 signaling by anti-Müllerian hormone and its type II receptor. Journal of Biological Chemistry $\mathbf{2 7 5}$ 27973-27978. (https://doi.org/10.1074/jbc.M002704200)

Grynberg M, Pierre A, Rey R, Leclerc A, Arouche N, Hesters L, CatteauJonard S, Frydman R, Picard JY, Fanchin R et al. 2012 Differential regulation of ovarian anti-Mullerian hormone $(\mathrm{AMH})$ by estradiol through alpha- and beta-estrogen receptors. Journal of Clinical Endocrinology and Metabolism 97 E1649-E1657. (https://doi.org/10.1210/jc.2011-3133)

Gustafson ML, Lee MM, Scully RE, Moncure AC, Hirakawa T, Goodman A, Muntz HG, Donahoe PK, MacLaughlin DT \& Fuller AF 1992 Müllerian inhibiting substance as a marker for ovarian sex-cord tumor. New England Journal of Medicine 326 466-471. (https://doi.org/10.1056/ NEJM199202133260707)

Hattori RS, Murai Y, Oura M, Masuda S, Majhi SK, Sakamoto T, Fernandino JI, Somoza GM, Yokota M \& Strussmann CA 2012 A Y-linked anti-Mullerian hormone duplication takes over a critical role in sex determination. PNAS 109 2955-2959. (https://doi.org/10.1073/ pnas.1018392109)

Hayashi M, Shima H, Hayashi K, Trelstad RL \& Donahoe PK 1984 Immunocytochemical localization of Müllerian inhibiting substance in the rough endoplasmic reticulum and Golgi apparatus in Sertoli cells of the neonatal calf testis using a monoclonal antibody. Journal of Histochemistry and Cytochemistry 32 649-654. (https://doi. org/10.1177/32.6.6373916)

Hossain A \& Saunders GF 2003 Synergistic cooperation between the $\beta$ catenin signaling pathway and steroidogenic factor- 1 in the activation of the Müllerian inhibiting substance type II receptor. Journal of Biological Chemistry 278 26511-26516. (https://doi.org/10.1074/jbc. M300804200) 
Hudson PL, Dougas I, Donahoe PK, Cate RL, Epstein J, Pepinsky RB \& MacLaughlin DT 1990 An immunoassay to detect human Müllerian inhibiting substance in males and females during normal development. Journal of Clinical Endocrinology and Metabolism 70 16-22. (https://doi. org/10.1210/jcem-70-1-16)

Jamin SP, Arango NA, Mishina Y, Hanks MC \& Behringer RR 2002 Requirement of bmpr 1 a for Müllerian duct regression during male sexual development. Nature Genetics 32 408-410. (https://doi.org/10.1038/ ng1003)

Josso N 1971 Interspecific character of the Müllerian-inhibiting substance: action of the human fetal testis, ovary and adrenal on the fetal rat Müllerian duct in organ culture. Journal of Clinical Endocrinology and Metabolism 32 404-409. (https://doi.org/10.1210/jcem-32-3-404)

Josso N 1972 Permeability of membranes to the Müllerian inhibiting substance synthesized by the human fetal testis. Journal of Clinical Endocrinology and Metabolism 34 265-270. (https://doi.org/10.1210/ jcem-34-2-265)

Josso N 1973 In vitro synthesis of Müllerian-inhibiting hormone by seminiferous tubules isolated from the calf fetal testis. Endocrinology $\mathbf{9 3}$ 829-834. (https://doi.org/10.1210/endo-93-4-829)

Josso N 2017 Le Sexe des Anges: Une Histoire d'Hormones. Paris: EDP Sciences.

Josso N, Forest MG \& Picard JY 1975 Mullerian-inhibiting activity of calf fetal testes: relationship to testosterone and protein synthesis. Biology of Reproduction 13 163-167. (https://doi.org/10.1095/biolreprod13.2.163)

Josso N, Legeai L, Forest MG, Chaussain JL \& Brauner R 1990 An enzyme-linked immunoassay for anti-Müllerian hormone: a new tool for the evaluation of testicular function in infants and children. Journal of Clinical Endocrinology and Metabolism 70 23-27. (https://doi. org/10.1210/jcem-70-1-23)

Jost A 1953 Problems of fetal endocrinology: the gonadal and hypophyseal hormones. Recent Progress in Hormone Research 8 379-418.

Kano M, Sosulski AE, Zhang L, Saatcioglu HD, Wang D, Nagykery N, Sabatini ME, Gao G, Donahoe PK \& Pepin D 2017 AMH/MIS as a contraceptive that protects the ovarian reserve during chemotherapy. PNAS 114 E1688-E1697. (https://doi.org/10.1073/pnas.1620729114)

Kobayashi A, Stewart CA, Wang Y, Fujioka K, Thomas NC, Jamin SP \& Behringer RR 2011 Beta-catenin is essential for Mullerian duct regression during male sexual differentiation. Development 138 1967-1975. (https://doi.org/10.1242/dev.056143)

Lasala C, Schteingart HF, Arouche N, Bedecarras P, Grinspon RP, Picard JY, Josso N, di Clemente N \& Rey RA 2011 Sox9 and SF1 are involved in cyclic AMP-mediated upregulation of anti-Mullerian gene expression in the testicular prepubertal Sertoli cell line SMAT1. American Journal of Physiology: Endocrinology and Metabolism 301 E539-E547. (https://doi. org/10.1152/ajpendo.00187.2011)

Lebeurrier N, Launay S, Macrez R, Maubert E, Legros H, Leclerc A, Jamin SP, Picard JY, Marret S, Laudenbach V et al. 2008 Anti-Mullerianhormone-dependent regulation of the brain serine-protease inhibitor neuroserpin. Journal of Cell Science 121 3357-3365. (https://doi. org/10.1242/jcs.031872)

Mamsen LS, Petersen TS, Jeppesen JV, Mollgard K, GrondahI ML, Larsen A, Ernst E, Oxvig C, Kumar A, Kalra B et al. 2015 Proteolytic processing of anti-Mullerian hormone differs between human fetal testes and adult ovaries. Molecular Human Reproduction 21 571-582. (https://doi. org/10.1093/molehr/gav024)

Morgan K, Ruffman T, Bilkey DK \& McLennan IS 2017 Circulating anti-Mullerian hormone (AMH) associates with the maturity of boys' drawings: does AMH slow cognitive development in males? Endocrine 57 528-534. (https://doi.org/10.1007/s12020-017-1333-2)

Morinaga C, Saito D, Nakamura S, Sasaki T, Asakawa S, Shimizu N, Mitani H, Furutani-Seiki M, Tanaka M \& Kondoh H 2007 The Hotei mutation of medaka in the anti-Mullerian hormone receptor causes the dysregulation of germ cell and sexual development. PNAS 104 9691-9696. (https://doi.org/10.1073/pnas.0611379104)

Nachtigal MW \& Ingraham HA 1996 Bioactivation of Mullerian inhibiting substance during gonadal development by a kex2/subtilisinlike endoprotease. PNAS 93 7711-7716. (https://doi.org/10.1073/ pnas.93.15.7711)

Nelson SM, Pastuszek E, Kloss G, Malinowska I, Liss J, Lukaszuk A, Plociennik L \& Lukaszuk K 2015 Two new automated, compared with two enzyme-linked immunosorbent, anti Mullerian hormone assays.
Fertility and Sterility 104 1016.e6-1021.e6. (https://doi.org/10.1016/j. fertnstert.2015.06.024)

Orvis GD, Jamin SP, Kwan KM, Mishina Y, Kaartinen VM, Huang S, Roberts AB, Umans L, Huylebroeck D, Zwijsen A et al. 2008 Functional redundancy of TGF-beta family type receptors and receptor-smads in mediating anti-Mullerian hormone-induced Mullerian duct regression in the mouse. Biology of Reproduction 78 994-1001. (https://doi. org/10.1095/biolreprod.107.066605)

Pankhurst MW \& McLennan IS 2016 A specific immunoassay for proAMH, the uncleaved proprotein precursor of anti-Mullerian hormone. Molecular and Cellular Endocrinology 419 165-171. (https://doi. org/10.1016/j.mce.2015.10.013)

Park SH, Chung YJ, Song JY, Kim SI, Pepin D, MacLaughlin DT, Donahoe PK \& Kim JH 2017 Mullerian inhibiting substance inhibits an ovarian cancer cell line via beta-catenin interacting protein deregulation of the Wnt signal pathway. International Journal of Oncology 50 1022-1028. (https://doi.org/10.3892/ijo.2017.3874)

Pellatt L, Hanna L, Brincat M, Galea R, Brain H, Whitehead S \& Mason H 2007 Granulosa cell production of anti-Mullerian hormone is increased in polycystic ovaries. Journal of Clinical Endocrinology and Metabolism 92 240-245. (https://doi.org/10.1210/jc.2006-1582)

Pepinsky RB, Sinclair LK, Chow EP, Mattaliano RJ, Manganaro TF, Donahoe PK \& Cate RL 1988 Proteolytic processing of Müllerian inhibiting substance produces a transforming growth factor-beta-like fragment. Journal of Biological Chemistry 263 18961-18964.

Pfennig F, Standke A \& Gutzeit HO 2015 The role of amh signaling in teleost fish - multiple functions not restricted to the gonads. General and Comparative Endocrinology 223 87-107. (https://doi.org/10.1016/j. ygcen.2015.09.025)

Picard JY \& Josso N 1976 Anti-Müllerian hormone: estimation of molecular weight by gel filtration. Biomedicine 25 147-150.

Picard JY \& Josso N 1984 Purification of testicular anti-Müllerian hormone allowing direct visualization of the pure glycoprotein and determination of yield and purification factor. Molecular and Cellular Endocrinology 34 23-29. (https://doi.org/10.1016/0303-7207(84)90155-2)

Picard JY, Tran D \& Josso N 1978 Biosynthesis of labelled anti-Müllerian hormone by fetal testes: evidence for the glycoprotein nature of the hormone and for its disulfide-bonded structure. Molecular and Cellular Endocrinology 12 17-30. (https://doi.org/10.1016/0303-7207(78)900989)

Picard JY, Benarous R, Guerrier D, Josso N \& Kahn A 1986 Cloning and expression of cDNA for anti-Müllerian hormone. PNAS 83 5464-5468. (https://doi.org/10.1073/pnas.83.15.5464)

Picard JY, Cate RL, Racine C \& Josso N 2017 The persistent Müllerian duct syndrome: an update based upon a personal experience of 157 cases. Sexual Development 11 109-125. (https://doi.org/10.1159/000475516)

Picon R 1969 Action du testicule foetal sur le développement in vitro des canaux de Müller chez le rat. Archives d'Anatomie Microscopique et de Morphologie Expérimentale 58 1-19.

Pierre A, Peigne M, Grynberg M, Arouche N, Taieb J, Hesters L, Gonzales J, Picard JY, Dewailly D, Fanchin R et al. 2013 Loss of LH-induced down-regulation of anti-Mullerian hormone receptor expression may contribute to anovulation in women with polycystic ovary syndrome. Human Reproduction 28 762-769. (https://doi.org/10.1093/humrep/ des460)

Pierre A, Racine C, Rey RA, Fanchin R, Taieb J, Cohen-Tannoudji J, Carmillo P, Pepinsky RB, Cate RL \& di Clemente N 2016 Most cleaved anti-Mullerian hormone binds its receptor in human follicular fluid but little is competent in serum. Journal of Clinical Endocrinology and Metabolism 101 4618-4627. (https://doi.org/10.1210/jc.2016-1742)

Pierre A, Taieb J, Giton F, Grynberg M, Touleimat S, El Hachem H, Fanchin R, Monniaux D, Cohen-Tannoudji J, di Clemente N et al. 2017 Dysregulation of the anti-Mullerian hormone system by steroids in women with polycystic ovary syndrome. Journal of Clinical Endocrinology and Metabolism 102 3970-3978. (https://doi.org/10.1210/jc.2017-00308)

Pigny P, Gorisse E, Ghulam A, Robin G, Catteau-Jonard S, Duhamel A \& Dewailly D 2016 Comparative assessment of five serum antiMullerian hormone assays for the diagnosis of polycystic ovary syndrome. Fertility and Sterility 105 1063.e3-1069.e3. (https://doi.org/10.1016/j. fertnstert.2015.12.023)

Pilsgaard F, Grynnerup AG, Lossl K, Bungum L \& Pinborg A 2018 The use of anti-Mullerian hormone for controlled ovarian stimulation in 
assisted reproductive technology, fertility assessment and counseling. Acta Obstetricia et Gynecologica Scandinavica 97 1105-1113. (https:// doi.org/10.1111/aogs.13334)

Racine C, Rey R, Forest MG, Louis F, Ferre A, Huhtaniemi I, Josso N \& di Clemente $\mathbf{N} 1998$ Receptors for anti-Mullerian hormone on Leydig cells are responsible for its effects on steroidogenesis and cell differentiation. PNAS 95 594-599. (https://doi.org/10.1073/pnas.95.2.594)

Rey R, Lordereau-Richard I, Carel JC, Barbet P, Cate RL, Roger M, Chaussain JL \& Josso N 1993 Anti-Müllerian hormone and testosterone serum levels are inversely related during normal and precocious pubertal development. Journal of Clinical Endocrinology and Metabolism 77 1220-1226. (https://doi.org/10.1210/jcem.77.5.8077315)

Rey RA, Lhommé C, Marcillac I, Lahlou N, Duvillard P, Josso N \& Bidart JM 1996 Anti-Müllerian hormone as a serum marker of granulosa-cell tumors of the ovary: comparative study with serum alpha-inhibin and estradiol. American Journal of Obstetrics and Gynecology 174 958-965. (https://doi.org/10.1016/S0002-9378(96)70333-2)

Roberts LM, Visser JA \& Ingraham HA 2002 Involvement of a matrix metalloproteinase in MIS-induced cell death during urogenital development. Development 129 1487-1496.

Salmon NA, Handyside AH \& Joyce IM 2004 Oocyte regulation of antiMullerian hormone expression in granulosa cells during ovarian follicle development in mice. Developmental Biology 266 201-208. (https://doi. org/10.1016/j.ydbio.2003.10.009)

Shi J, Yoshino O, Osuga Y, Koga K, Hirota Y, Hirata T, Yano T, Nishii O \& Taketani Y 2009 Bone morphogenetic protein-6 stimulates gene expression of follicle-stimulating hormone receptor, inhibin/activin beta subunits, and anti-Mullerian hormone in human granulosa cells. Fertility and Sterility 92 1794-1798. (https://doi.org/10.1016/j. fertnstert.2009.05.004)

Sonigo C, Beau I, Grynberg M \& Binart N 2019 AMH prevents primordial ovarian follicle loss and fertility alteration in cyclophosphamidetreated mice. FASEB Journal 33 1278-1287. (https://doi.org/10.1096/ fj.201801089R)

Taieb J, Grynberg M, Pierre A, Arouche N, Massart P, Belville C, Hesters L, Frydman R, Catteau-Jonard S, Fanchin R et al. 2011 FSH and its second messenger cAMP stimulate the transcription of human anti-Mullerian hormone in cultured granulosa cells. Molecular Endocrinology 25 645-655. (https://doi.org/10.1210/me.2010-0297)

Tran D, Picard JY, Campargue J \& Josso N 1987 Immunocytochemical detection of anti-Müllerian hormone in Sertoli cells of various mammalian species, including man. Journal of Histochemistry and Cytochemistry 35 733-743. (https://doi.org/10.1177/35.7.3295030)

van Rooij IAJ, Broekmans FJM, teVelde ER, Fauser BCJM, Bancsi LFJM, de Jong FH \& Themmen AP 2002 Serum anti-Müllerian hormone levels: a novel measure of ovarian reserve. Human Reproduction 17 3065-3071. (https://doi.org/10.1093/humrep/17.12.3065)

Vigier B, Legeai L, Picard JY \& Josso N 1982a A sensitive radioimmunoassay for bovine anti-Müllerian hormone, allowing its detection in male and freemartin fetal serum. Endocrinology 111 1409-1411. (https://doi. org/10.1210/endo-111-4-1409)

Vigier B, Picard JY \& Josso N 1982b A monoclonal antibody against bovine anti-Müllerian hormone. Endocrinology 110 131-137. (https:// doi.org/10.1210/endo-110-1-131)

Vigier B, Picard JY, Tran D, Legeai L \& Josso N 1984 Production of antiMüllerian hormone: another homology between Sertoli and granulosa cells. Endocrinology 114 1315-1320. (https://doi.org/10.1210/endo114-4-1315)

Visser JA, Olaso R, Verhoef-Post M, Kramer P, Themmen AP \& Ingraham HA 2001 The serine/threonine transmembrane receptor ALK2 mediates Müllerian inhibiting substance signaling. Molecular Endocrinology 15 936-945. (https://doi.org/10.1210/mend.15.6.0645)

Visser JA, de Jong FH, Laven JS \& Themmen AP 2006 Anti-Müllerian hormone: a new marker for ovarian function. Reproduction 131 1-9. (https://doi.org/10.1530/rep.1.00529)

Visser JA \& Themmen APN 2014 Role of anti-Mullerian hormone and bone morphogenetic proteins in the regulation of FSH sensitivity. Molecular and Cellular Endocrinology 382 460-465. (https://doi.org/10.1016/j. mce.2013.08.012)

Wang PY, Koishi K, McGeachie AB, Kimber M, MacLaughlin DT, Donahoe PK \& McLennan IS 2005 Mullerian inhibiting substance acts as a motor neuron survival factor in vitro. PNAS 102 16421-16425. (https:// doi.org/10.1073/pnas.0508304102)

Wilson CA, di Clemente N, Ehrenfels C, Pepinsky RB, Josso N, Vigier B \& Cate RL 1993 Müllerian inhibiting substance requires its $\mathrm{N}$-terminal domain for maintenance of biological activity, a novel finding within the TGF-beta superfamily. Molecular Endocrinology 7 247-257. (https://doi. org/10.1210/mend.7.2.8469238)

Wittmann W \& McLennan IS 2011 The male bias in the number of Purkinje cells and the size of the murine cerebellum may require Mullerian inhibiting substance/anti-Mullerian hormone. Journal of Neuroendocrinology 23 831-838. (https://doi.org/10.1111/j.13652826.2011.02187.x)

Yamamoto Y, Zhang Y, Sarida M, Hattori RS \& Strussmann CA 2014 Coexistence of genotypic and temperature-dependent sex determination in pejerrey odontesthes bonariensis. PLOS ONE 9 e102574. (https://doi. org/10.1371/journal.pone.0102574)

Received 26 November 2018

First decision 4 February 2019

Revised manuscript received 19 February 2019

Accepted 7 March 2019 